\title{
Neuromyelitis optica of very late onset: one more case
}

\author{
Neuromielite óptica de início tardio: descrição de outro caso \\ Tiberio Araujo Amorim'; Pedro Augusto Sampaio Rocha-Filho 1,2
}

Dear editors,

We read with extreme interest the paper by Souza et al. ${ }^{1}$ This study describes one case of a 75-year-old woman with neuromyelitis optica (NMO) $)^{1}$. Including this case, only six cases of neuromyelitis optica developing after the age of 70 have been reported. We think that it is important to describe our recent experience.

A 72-year-old Caucasian woman sought our service complaining of a rapidly progressive visual loss in the right eye. After a further week, the other eye was affected, culminating in complete bilateral blindness in less than 15 days. The patient also developed paraparesis, becoming paraplegic in this period. On physical examination she had a T4 sensory level associated with significant dysesthesia. Her magnetic resonance image showed lesions in three contiguous spinal cord levels (T2-T4) and absence of any brain lesions suggestive of multiple sclerosis. Computed tomography scans of the chest, abdomen and pelvis were normal. A CSF analysis showed a cell count of 11 cells $/ \mathrm{mm}^{3}(36 \%$ lymphocytes, $60 \%$ monocytes), glucose $75 \mathrm{mg} \%$ and proteins $68 \mathrm{mg} \%$. Tests for syphilis, bacteria, fungi, herpes simplex, herpes zoster, cytomegalovirus, HTLV and HIV were negative. There were no oligoclonal bands. Serum assays on anti-DNA antibodies, anti-nuclear factor, anti-neutrophil cytoplasmic antibodies (p-ANCA and c-ANCA), anti-Ro (SSA), anti-La (SSB), anti-SM and rheumatoid factor, together with the serological test for the human immunodeficiency virus (HIV), were negative. Although she had not been tested for NMO-IgG, our patient fulfilled the diagnostic criteria for neuromyelitis optica².

The patient underwent pulse therapy with methylprednisolone for five days ${ }^{3}$. Her visual deficit showed some improvement. Immunoglobulin tests and plasmapheresis were not carried out owing to infectious complications that developed later. Our patient was released from the hospital with oral corticosteroids prescribed. Further evaluation is still necessary to establish whether the patient has shown any further improvement or relapses.

\section{References}

1. Souza CS, Brooks JB, Oliveira CL, Fragoso YD. Neuromyelitis optica with very late onset. Arq Neuropsiquiatr 2013;71:556-557.

2. Wingerchuk DM, Lennon VA, Pittock SJ, Lucchinetti CF, Weinshenker BG. Revised diagnostic criteria for neuromyelitis optica. Neurology 2006;66:1485-1489.
Sato D, Callegaro D, Lana-Peixoto MA, Fujihara K. Treatment of neuromyelitis optica: an evidence based review. Arq Neuropsiquiatr 2012;70:59-66.

\footnotetext{
'Divisão de Neurologia, Hospital Universitário Oswaldo Cruz, Universidade Federal de Pernambuco, Recife PE, Brazil. ${ }^{2}$ Departamento de Neuropsiquiatria, Universidade Federal de Pernambuco, Recife PE, Brazil.

Correspondence: Pedro Augusto Sampaio Rocha Filho, Rua General Joaquim Inacio, 830, Sala 1412 - Edf The Plaza Business Center; $50070-270$ Recife PE Brasil.E-mail: pasrf@ig.com.br

Conflict of Interest: There is no conflict of interest to declare.

Received 17 September 2013; Accepted 25 September 2013.
} 